\title{
Functional properties of newly bred Picnic apple (Malus pumila Mill.)
}

\author{
Eun-Ho Lee ${ }^{1} \cdot$ Eun-Bi Cho $^{1} \cdot$ Ji-Yang Lee $^{1} \cdot$ Jin-Hee Bae $^{1} \cdot$ Eun-Chul Lee $^{2}$. \\ Jin-Gi Yoo ${ }^{3} \cdot$ In-Kyu Kang ${ }^{3}$ Young-Je Cho ${ }^{1}$ (D)
}

\section{신육성 품종인 피크닉 (Picnic; Malus pumila Mill.) 사과의 기능성}

\author{
이은호 ${ }^{1} \cdot$ 조은비 $^{1} \cdot$ 이지양 ${ }^{1} \cdot$ 배진희 $^{1} \cdot$ 이은철 $^{2} \cdot$ 유진기 $^{3} \cdot$ 강인규 $^{3} \cdot$ 조영제 $^{1}$
}

Received: 28 March 2019 / Accepted: 16 May 2019 / Published Online: 30 June 2019

(C) The Korean Society for Applied Biological Chemistry 2019

\begin{abstract}
The newly bred Picnic apple was extracted using water and ethanol for extracting solvent. Each water and ethanol extract showed relatively high phenolic compound of 3.69 and $5.55 \mathrm{mg} / \mathrm{g}$. Each water and ethanol extract of Picnic apple showed 1,1-diphenyl-2-picrylhydrazyl of 88.10 and $88.07 \%$, 2,2'-Azinobis(3-ethylbenzothiazoline-6-sulfonic acid) of 98.79 and $97.25 \%$, antioxidant protection factor of 2.07 and $2.00 \mathrm{PF}$ and thiobarbituric acid reactive substances showed anti-oxidation effect of 9.69 and $19.83 \%$ all at $100 \mu \mathrm{g} / \mathrm{mL}$ phenolics concentration. Therefore extract of Picnic apple can be considered as anti-oxidant for antiaging. The anti-inflammatory effect (hyaluronidase inhibition) of extract of Picnic apple were $4.62 \%$ with water extract and $4.39 \%$ with ethanol extract both at $200 \mu \mathrm{g} / \mathrm{mL}$ phenolics concentration. Both water and ethanol extract showed low $\alpha$-amylase inhibition effect but each showed 67.37 and $79.16 \%$ of $\alpha$-glucosidase inhibition effect at $200 \mu \mathrm{g} / \mathrm{mL}$ phenolics concentration. In anti-wrinkle effect, water extract showed each 23.70 and $66.29 \%$ in elastase inhibition and collagenase inhibition and ethanol extract showed
\end{abstract}

Young-Je Cho $(\bowtie)$

E-mail: yjcho@knu.ac.kr

${ }^{1}$ School of Food science \& Biotechnology, Kyungpook National University, 80 Daehakro, Bukgu, Daegu 41566, Republic of Korea

${ }^{2}$ Department of Food and Food Service Industry, Kyungpook National University, 2559 Gyeongsangdaero, Sangju 37224, Republic of Korea

${ }^{3}$ Department of Horticultural Science, Kyungpook National University, 80 Daehakro, Bukgu, Daegu 41566, Republic of Korea

This is an Open Access article distributed under the terms of the Creative Commons Attribution Non-Commercial License (http://creativecommons. org/licenses/by-nc/3.0/) which permits unrestricted non-commercial use, distribution, and reproduction in any medium, provided the original work is properly cited.
64.83 and $65.70 \%$ each. These result show high potential for functional food and cosmetic source. Picnic apple was identified to have various functions of anti-oxidation, anti-inflammation, anti-wrinkle effect, and anti-diabetic effect. Therefore, Picnic apple is qualified as a source for new functional cosmetics and functional foods.

Keywords Biological activities · Functional beauty food $\cdot$ Healthy functional foods · Newly bred · Picnic apple

\section{서 론}

최근 1 인가구의 증가로 작은 단위로 포장된 제품들이 인기를 끄는 것과 같이 사과 또한 작은 품종이 인기를 얻고 있는 추세 이다. 최근 발표된 '2018농업전망'에 따르면 가정용 사과의 경 우 소과 $(213 \mathrm{~g}$ 이하)를 선호하는 비율이 2014년 8.7\%에서 2017 년 $16.6 \%$ 로 두배 가까이 증가 한 반면, 대과 $(300 \mathrm{~g}$ 이상)는 $9.4 \%$ 에서 $3.9 \%$ 로 두 배 이상 감소했다. 선물용도 중과 선호비 중은 상승한 반면 대과는 감소하는 추세를 보였으며, 농촌경제 연구원의 발표에 따르면 중,소과 사과가격이 대과에 비해 9-22\% 까지 상승했다고 한다[1].

사과나무는 우리나라에서 전체 과수 재배 면적의 $40 \%$ 를 차 지하며 장미과(Rosaceae)에 속하는 북부 온대과수이다. 식물 화 학연구의 결과에 따르면 사과는 다당류, 식물성 스테롤, 페놀, 단백질, 비타민 뿐만 아니라 인간이 필요로 하는 필수 미량원 소들을 포함하고 있으며, 특히 사과껍질은 과육에 비해 2-9배로 높은 폴리페놀 함량을 나타낸다고 보고되었다[2-4]. 폴리페놀은 사과의 주요한 항산화 물질이며[5,6], 항염증효과, 항종양효과 등 을 나타내어 인간의 건강에 유익한 효과가 있음이 입증된 물질 이다[7,8]. 
피크닉(Malus pumila Mill) 사과 품종은 야외로 소풍 갈 때 먹기 좋은 사과라 해서 '피크닉'이라 이름이 붙여졌으며 후지와 산사 품종을 교배해 만든 신품종으로 테니스 공 크기이며, 무 게가 약 $220 \mathrm{~g}$ 정도의 빨간색 중, 소과 사과로 보통 9월 중순 에서 10 월 초에 수확된다.

본 연구에서는 경북 군위의 사과연구소에서 품종이 개발되어 경북예천 지방에서 지역특화품종으로 품질을 인정받고 있는 피 크닉 사과의 항산화 효과와 주름개선효과, 미백효과 등 다양한 미용생리활성 효과를 살펴보고 이 연구를 통해 항산화 및 화장 품 소재로서의 개발 가능성을 검토하였다.

\section{재료 및 방법}

\section{시험 재료}

시험재료는 경북 군위군 소재의 사과연구소에서 교배조합으로 후지 품종(모본)과 산사 품종(부본)을 이용하여 교배하여 육성 한 신 육성 품종인 피크닉(Picnic) 사과를 사용하였다. 시료는 사과연구소의 실습 포장에서 재배되고 있는 피크닉 사과나무로 부터 붉은색으로 완숙된 사과를 수확한 후 이물질을 제거하고 whole 사과를 대상으로 실험하였다. Whole 사과 시료는 $1 \mathrm{~cm}$ 두께로 슬라이스한 후 동결건조(freeze dryer, FD8518, Ilshinbiobase, Yangju, Korea)하여 수분을 제거하고 $40 \mathrm{mesh}$ 로 분쇄하여 4 ${ }^{\circ} \mathrm{C}$ 저온고에 보관하며 시료로 사용하였다.

\section{피크닉 사과로부터 phenol성 추출물 제조}

기능성 식품 및 기능성 화장품 활성 분석을 위한 추출물의 제 조는 열수 추출물의 경우 피크닉 사과의 시료 분말 $1 \mathrm{~g}$ 을 증 류수 $200 \mathrm{~mL}$ 에 침지하여 추출물은 heating stir에서 $100^{\circ} \mathrm{C}$ 이 상으로 가열하여 액이 $100 \mathrm{~mL}$ 가 될 때까지 가열, 증발시킨 후 냉각하고 $4{ }^{\circ} \mathrm{C}$ 의 shaking incubator에서 24 시간 동안 교반, 추출 하였으며, ethanol 추출물의 경우에는 피크닉 사과 분말 $1 \mathrm{~g}$ 에 $10-100 \%$ 농도의 ethanol $100 \mathrm{~mL}$ 를 첨가하여 $4{ }^{\circ} \mathrm{C}$ 의 shaking incubator에서 24시간 동안 교반, 추출하였다. 각 추출물은 Whatman No. 1 filter paper (Whatman Inc., Piscataway, New Jersey, USA)로 여과한 후 필요에 따라 rotary vacuum evaporator (Eyela NE, Tokyo, Japan)에서 농축하여 $4{ }^{\circ} \mathrm{C}$ 냉장고에서 저온 보관하며, 시료의 phenolic compounds 농도를 각각 25,50 , $75,100 \mu \mathrm{g} / \mathrm{mL}$ 또는 $50,100,150,200 \mu \mathrm{g} / \mathrm{mL}$ phenolics 농도 로 설정하여 실험에 사용하였다.

\section{Total phenolic compounds 함량 정량}

Total phenolic 정량은 Folin과 Denis의 방법[9]에 준하여 추출 물 $1 \mathrm{~mL}$ 에 $95 \%$ ethanol $1 \mathrm{~mL}$ 와 증류수 $5 \mathrm{~mL}$ 를 첨가하고 $1 \mathrm{~N}$ Folin-ciocalteu reagent $0.5 \mathrm{~mL}$ 를 잘 섞어 5 분간 방치한 후 $\mathrm{Na}_{2} \mathrm{CO}_{3} 1 \mathrm{~mL}$ 를 가하여 흡광도 $725 \mathrm{~nm}$ 에서 1 시간 이내에 측정 하여 gallic acid를 이용한 표준곡선으로부터 양을 환산하였다.

\section{1,1-diphenyl-2-picrylhydrazyl (DPPH) radical 저해 효과}

$\mathrm{DPPH}$ radical 저해 효과 측정은 Blois의 방법[10]에 준하여, 시 료 $0.5 \mathrm{~mL}$ 에 $60 \mu \mathrm{M} \mathrm{DPPH} 3 \mathrm{~mL}$ 를 넣고 vortex한 후 15 분 동안 방치한 다음 $517 \mathrm{~nm}$ 에서 흡광도를 측정하였다.
2,2'-Azinobis-(3-ethylbenzothiazoline-6-sulfonic acid) (ABTS) radical 저해 효과

ABTS radical 저해 효과 측정은 Pellegrini 등의 방법[11]에 준 하여, 시료 $7 \mathrm{mM} \mathrm{ABTS}$ 와 $140 \mathrm{mM} \mathrm{K} \mathrm{S}_{2} \mathrm{O}_{8}$ 을 $5 \mathrm{~mL}: 88 \mu \mathrm{L}$ 로 섞어 어두운 곳에 12-16시간 방치시킨 후, 이를 ethanol과 1:88 의 비율로 섞어 $734 \mathrm{~nm}$ 에서 대조구의 흡광도 값이 $0.7 \pm 0.02$ 가 되도록 조절한 $\mathrm{ABTS}$ solution을 사용하여 시료용액 $50 \mu \mathrm{L}$ 와 ABTS solution $1 \mathrm{~mL}$ 를 30 초 동안 섞은 후 2.5 분간 incubation 하여 $734 \mathrm{~nm}$ 에서 흡광도를 측정하였다.

\section{Antioxidant protection factor (PF) 측정}

$\mathrm{PF}$ 측정은 Andarwulan과 Shetty의 방법[12]에 준하여, $10 \mathrm{mg}$ 의 $\beta$-carotene을 $50 \mathrm{~mL}$ 의 chloroform에 녹인 용액 $1 \mathrm{~mL}$ 를 evaporator용 수기에 넣고 40 water bath에서 chloroform을 증 류시킨 후 $20 \mu \mathrm{L}$ linoleic acid, $184 \mu \mathrm{L}$ tween 40 과 $50 \mathrm{~mL}$ $\mathrm{H}_{2} \mathrm{O}_{2}$ 를 가하여 emulsion을 만들고, $5 \mathrm{~mL}$ 의 emulsion에 시료 $100 \mu \mathrm{L}$ 를 혼합하여 vortex로 잘 섞어 준 뒤 $50{ }^{\circ} \mathrm{C}$ 에서 30 분간 반응 시켜 냉각시킨 다음, $470 \mathrm{~nm}$ 에서 흡광도를 측정하였다.

Thiobarbituric acid reactive substances (TBARs) 저해 효과 TBARs 저해 효과 측정은 Buege와 Aust의 방법[13]에 준하여, $1 \%$ linoleic acid와 $1 \%$ Tween 40으로 emulsion을 만들고 emulsion $0.8 \mathrm{~mL}$ 와 시료 $0.2 \mathrm{~mL}$ 를 섞은 후 $50{ }^{\circ} \mathrm{C}$ water bath 에서 10 시간 반응시켰다. 반응액 $1 \mathrm{~mL}$ 에 regent $2 \mathrm{~mL}$ 를 가하고 15 분간 boiling한 다음 10 분간 냉각시키고, 15 분간 $1,000 \mathrm{rpm}$ 으 로 원심분리하여 실온에서 10 분간 방치 후 상등액을 $532 \mathrm{~nm}$ 에 서 흡광도를 측정하였다.

\section{Hyaluronidase (HAase) 저해 효과}

HAase 저해 효과는 Dorfman와 OTT의 방법[14]에 준하여, sodiumhyaluronic acid (HA)로부터 형성된 N-acetyl-glucosamine을 glucoxazoline 유도체로 변형시킨 후 $\rho$-dimethyl-aminobenzaldehyde (DMAB)로 발색시켜 $600 \mathrm{~nm}$ 에서 투과율을 측정하였다.

\section{Elastase 효소저해 효과}

Elastase 저해 효과는 Kraunsoe 등의 방법[15]에 준하여, $0.2 \mathrm{M}$ Tris-HCl buffer (pH 8.0) $1 \mathrm{~mL}$ 에 기질액 $0.8 \mathrm{mM} \mathrm{N}$-succinyl(Ala) $)_{3}$ - $\rho$-nitroanilide 용액 $0.1 \mathrm{~mL}$ 의 혼합액에 $1.0 \mathrm{U} / \mathrm{mL}$ porcine pancreatic elastase (PPE) (Sigma-Aldrich Co., St. Louis, MO, USA) 효소용액 $0.1 \mathrm{~mL}$ 와 $50-200 \mu \mathrm{g} / \mathrm{mL}$ phenolic compounds 농도의 각 시료 $0.1 \mathrm{~mL}$ 를 넣고 대조구에는 시료 대신 증류수 $0.1 \mathrm{~mL}$ 를 첨가하여 $25^{\circ} \mathrm{C}$ 에서 20 분간 반응시킨 후 $\rho$-nitroaniline 생성량을 흡광도 $410 \mathrm{~nm}$ 에서 측정하였다.

\section{Collagenase 효소저해 효과}

Collagenase 저해 효과 측정은 Wunsch와 Heidrich의 방법[16]에 준하여, $0.1 \mathrm{M}$ Tris- $\mathrm{HCl}$ buffer $(\mathrm{pH} 7.5)$ 에 $4 \mathrm{mM} \mathrm{CaCl} 2$ 를 첨 가하여 4-phenylazobenzyloxycarbonyl-Pro-Leu-Gly-Pro-D-Arg $(0.3 \mathrm{mg} / \mathrm{mL})$ 를 녹인 기질액 $0.25 \mathrm{~mL}$ 와 $50-200 \mu \mathrm{g} / \mathrm{mL}$ phenolic compounds 농도의 각 시료 용액 $0.1 \mathrm{~mL}$ 의 혼합액에 $0.2 \mathrm{mg}$ / $\mathrm{mL}$ collagenase (Sigma-Aldrich Co., St. Louis, MO, USA) $0.15 \mathrm{~mL}$ 를 첨가하여 실온에서 20 분간 방치한 후 $6 \%$ citric acid 

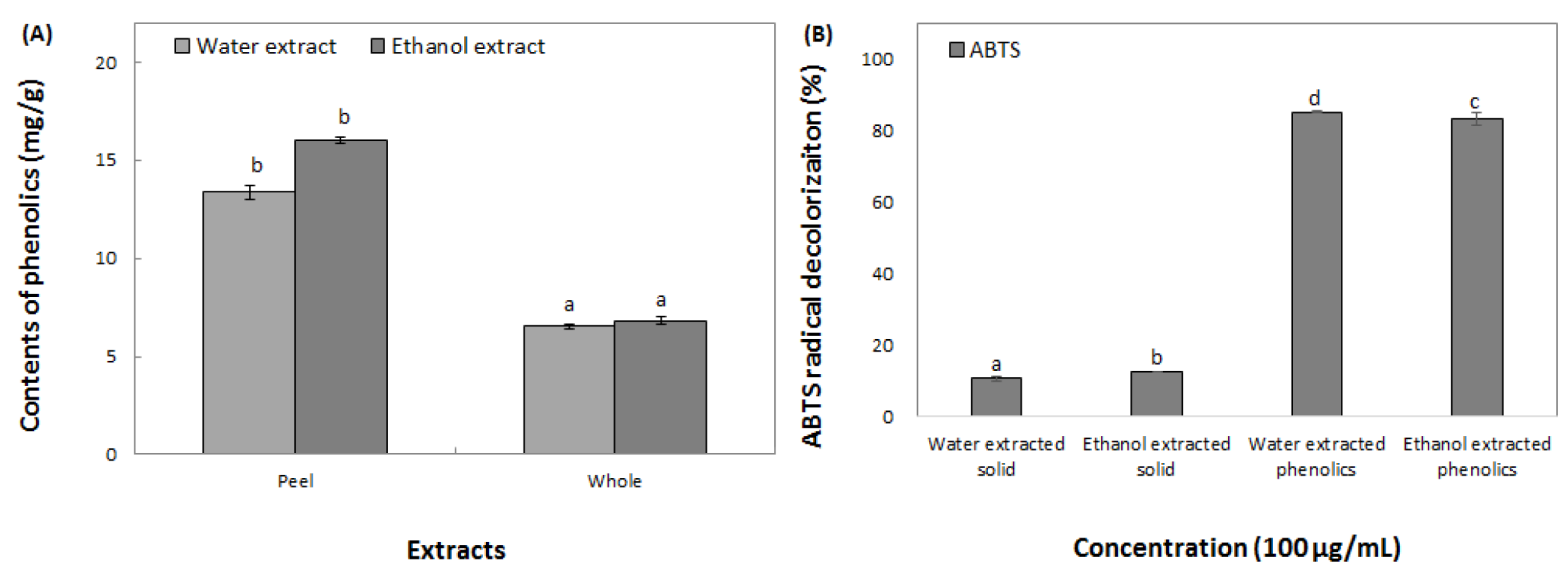

Fig. 1 The content of phenolic content (A) in Picnic apple and ABTS antioxidant activity (B) of solid and phenolics in picnic apple. Means with different superscript letters are significantly different at $p<0.05$ by a Duncan's multiple range tests

$0.5 \mathrm{~mL}$ 를 넣어 반응을 정지시킨 다음, ethyl acetate $2 \mathrm{~mL}$ 를 첨 가하고 $320 \mathrm{~nm}$ 에서 흡광도를 측정하였다.

\section{통계처리}

모든 실험은 3회 이상 반복 측정하였고 자료의 통계처리는 SPSS 23 for windows (Statistical Package for Social Science, SPSS Inc., Chicago, IL, USA)를 이용하여 평균 \pm 표준편차 (mean \pm standard deviation)로 표시하였고 분산분석 Duncan's multiple range test, one-way ANOVA를 실시하여 시료 간의 유의차를 $p<0.05$ 수준으로 비교 분석하였다.

\section{결과 및 고찰}

\section{신육성 품종인 피크닉 사과의 껍질, whole 사과 추출물의 고형 분과 phenolic의 생리활성 비교}

Polyphenol류는 식물체에 널리 분포하며, 자외선에 의한 산화, 곤충 및 미생물의 오염에 의한 피해로부터 자신을 스스로 보호 하기 위한 방어기작으로 생산하는 파이토케미칼 물질로서 세포 내에서 생산되며, 식물에게는 방어 기작으로 이용되고 있으나, 인간들에게 적용되면 항당뇨, 항염증, 항고혈압, 항관절염 등의 약리적 작용을 수행하며 beauty food 분야에서는 항산화를 비 롯한 미백, 주름개선 등의 다양한 미용활성을 나타내게 된다[17]

사과 신육성품종 피크닉 껍질, whole 사과 추출물의 phenolic 함량을 측정한 결과 껍질의 물과 ethanol 추출물에서 Fig. $1 \mathrm{~A}$ 에서와 같이 13.36 과 $16.02 \mathrm{mg} / \mathrm{g}$ 으로 ethanol 추출물에서 더 높 은 phenolic 함량을 나타내었고 whole 사과에서는 물과 ethanol 추출물에서 6.53 과 $6.82 \mathrm{mg} / \mathrm{g}$ 으로 측정되어 껍질 추출물이 whole 사과 추출물보다 약 2.4 배 정도의 높은 함량을 나타내었다. 이 등[18]은 그린볼사과 껍질의 ethanol 추출물에서 $8.31 \mathrm{mg} / \mathrm{g}$, whole 사과의 ethanol 추출물은 $3.49 \mathrm{mg} / \mathrm{g}$ 의 phenolic 함량을 나타내었다고 보고하였으며, 피크닉 사과의 껍질과 whole 사과 의 phenolic 함량이 더 높은 것을 확인할 수 있었다. 사과의 고 형분과 phenolic 성분의 생리활성 효능을 비교를 위해 $\mathrm{ABTS}$ radical 소거능을 측정한 결과 Fig. $1 \mathrm{~B}$ 에서와 같이 피크닉 사과 의 water, ethanol 추출물 $100 \mu \mathrm{g} / \mathrm{mL}$ 농도의 고형분에서 각각
$10.51 \%$ 와 $12.51 \%$ 의 ABTS radical 소거능을 나타내었으나, $100 \mu \mathrm{g} / \mathrm{mL}$ 농도의 phenolic compound를 첨가하였을 때는 각각 $85.16 \%$ 와 $83.2 \%$ 의 ABTS radical 소거능을 나타내어 사과의 생 리활성에는 고형분 중에 함유된 페놀성 물질에 의해 활성이 나 타나는 것으로 확인되었다. 사과에는 procyanidin, chlorogenic acid, caffeic acid, epicatechin, catechin, p-coumaroylquinic acid, rutin, phloridzin, quercetin과 같은 다양한 페놀성 물질이 존재하고, 이들 페놀성 물질들이 다양한 생리활성에 관여한다고 알려져 있으며[19,20], 이러한 페놀성 물질 중 일부는 다양한 식 물에서 발견되는 천연물로 알려져 있다. 상기의 결과에 의해 피 크닉 사과도 이러한 페놀성 물질들에 의해 생리활성이 지배되 는 것으로 추측되었다.

\section{신육성 품종인 피크닉 사과의 용매 농도별 phenolic compound 추출수율 비교}

생리활성물질의 분리에는 다양한 방법이 적용되고 있으나 그 중 추출은 식물체에 함유된 생리활성 물질을 분리하는 간단하면서 도 효과적인 방법이다. 추출에 사용되는 용매의 종류와 적용농 도는 추출물의 생리활성 검정 단계에서 효능발현에 막대한 영 향을 미치는데 이는 추출 시 분리되는 phenolic compound의 profile과 추출수율에 기인되기도 한다. 열수 추출은 용매에 대 한 유해성이 없어 수용성 물질 추출에 많이 이용되고 있고, 극 성 용매인 에탄올을 이용한 추출의 경우, flavonoid류, phenolics, tannin류 및 다양한 유기물질의 추출에 유리하게 작 용된다[21].

신육성품종 피크닉 사과 추출물의 ethanol 농도별 phenolic 함 량을 측정한 결과 Fig. 2에서와 같이 사과의 ethanol 농도별 추 출에서는 $40-80 \%$ 의 ethanol 농도군에서 비슷한 용출율을 나타 내었으나, $40 \%$ ethanol 추출물에서 $5.55 \mathrm{mg} / \mathrm{g}$ 으로 phenolic 함 량의 가장 높은 추출 수율을 나타내었다. 따라서 높은 추출 수 율과 기능성 식품 및 기능성 화장품에 적용시키기 위하여 피크 닉 사과를 water와 $40 \%$ ethanol을 용매로 사용하여 추출물을 제조하였다. 위의 결과에 따라 water, $40 \%$ ethanol로 추출한 추 출물을 실험의 재현성을 위해 phenolic 함량을 $25-200 \mu \mathrm{g} / \mathrm{mL}$ 으 로 조절하여 항산화 효과, 건강기능성 식품 및 기능성 화장품 활성을 검증하였다. 


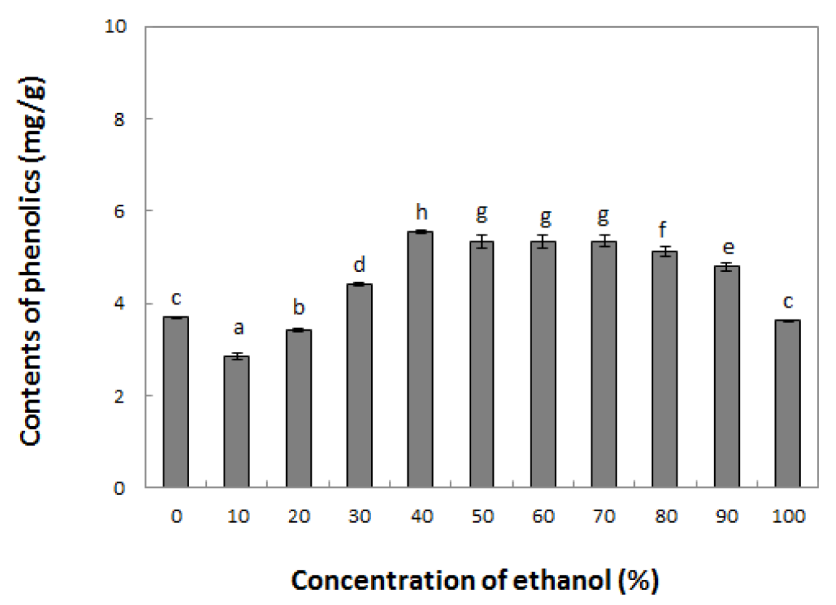

Fig. 2 The content of phenolic content in extracts from Picnic apple by various ethanol concentration. Means with different superscript letters are significantly different at $p<0.05$ by a Duncan's multiple range tests

\section{신육성 품종인 피크닉 사과의 항산화 효과}

항산화제는 식품의 산화를 방지하고 인체에서는 노화 방지, 성 인병 예방 등의 기능을 수행할 수 있는 천연물질로 약리적 기 능을 수행한다[22,23]. 항산화제는 반응성이 높아 체내 유해물 질과 반응하여 세포내 주요 물질들이 활성산소에 의한 연쇄반 응을 막아 주어 세포를 보호하는 역할을 하며, 체내에는 항산
화 효소계인 superoxide dismutase, catalase, glutathione peroxidase, glutathione S-transferase 등이 존재하며, 저분자 항산화제 혹은 free radical scavenger 역할을 하는 vitamin $\mathrm{C}$, vitamin $\mathrm{E}, \beta$ carote in, carotenoids, flavonoids, selenium 및 몇 가지 무기질 등이 항산화 기능을 수행하는 것으로 알려져 있다[24].

피크닉 사과 추출물의 항산화 효과를 평가하기 위해 $\mathrm{DPPH}$ radical 소거능을 측정한 결과 Fig. $3 \mathrm{~A}$ 에서와 같이 피크닉 사과 의 water, ethanol 추출물의 $25-100 \mu \mathrm{g} / \mathrm{mL}$ phenolic 농도에서 각각 86.01-88.10, 85.33-88.07\%의 radical 소거능을 나타내었다. 피크닉 사과의 추출물을 이용하여 ABTS radical 소거능을 측정 한 결과 Fig. $3 \mathrm{~B}$ 에서와 같이 피크닉 사과의 water, ethanol 추 출물의 $25-100 \mu \mathrm{g} / \mathrm{mL}$ phenolic 농도에서 각각 44.84-98.79, $36.93-97.25 \%$ 의 매우 높은 radical 소거능을 나타내었다.

11 개의 이중 결합으로 구성되어 있어 높은 불포화 성질을 가 지고 있는 $\beta$-carotine은 peroxyl radical과 매우 쉽게 반응하는데 불포화된 탄소 중 하나에 선택적 연쇄 절단되어 항산화제로서 작용하는 성질을 이용하여 지용성 항산화능을 나타내는 $\mathrm{PF}$ 를 측정한 결과 Fig. 3 C에서와 같이 피크닉 사과의 water, ethanol 추출물의 $25-100 \mu \mathrm{g} / \mathrm{mL}$ phenolic 농도에서 각각 $1.60-2.07 \mathrm{PF}$, 1.48-2.00 PF를 나타내어, 피크닉사과 추출물이 우수한 지용성 항산화능을 나타내는 것을 확인하였다. 피크닉 사과 추출물을 이용하여 또 다른 지용성 항산화능을 나타내는 TBARs를 측정 한 결과 Fig. $3 \mathrm{D}$ 에서와 같이 피크닉 사과의 water, ethanol 추 출물에서 각각 $9.67-24.55,0.03-19.83 \%$ 의 활성을 나타내었다.
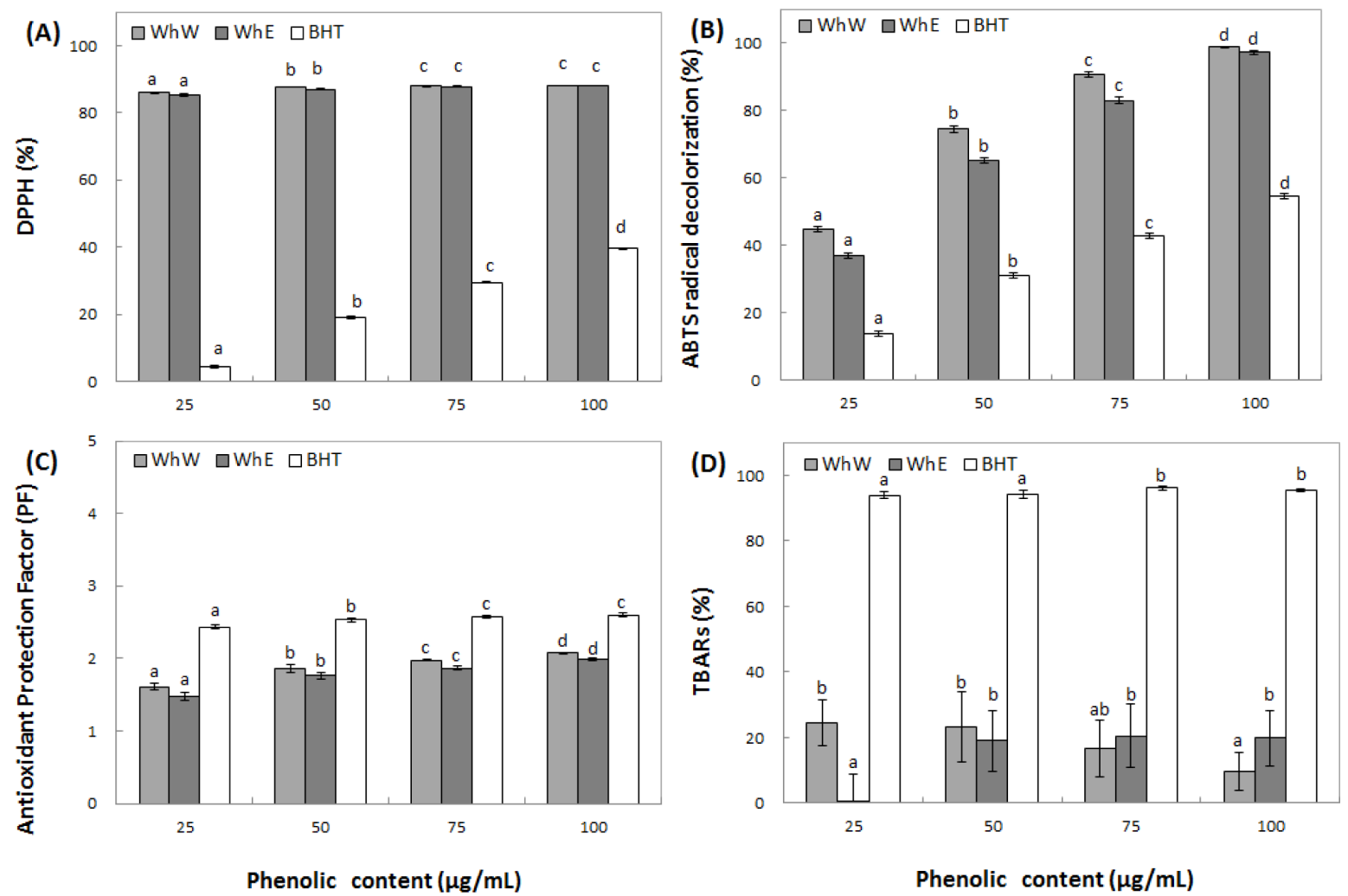

Fig. 3 Antioxidant activity of water and ethanol extracts from Picnic apple. A) DPPH, B) ABTS, C) PF, D) TBARs. Means with different superscript letters are significantly different at $p<0.05$ by a Duncan's multiple range tests. 1) WhW: whole fruit water extracts and 2) WhE: whole fruit ethanol extracts 


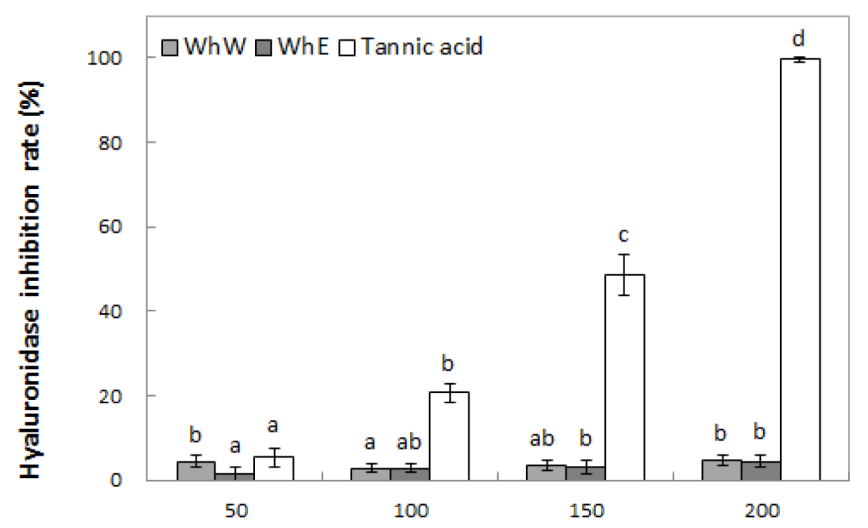

Phenolic content $(\mu \mathrm{g} / \mathrm{mL})$

Fig. 4 Inhibition activity of water and ethanol extracts from Picnic apple on hyaluronidase. Means with different superscript letters are significantly different at $p<0.05$ by a Duncan's multiple range tests. 1 ) WhW: whole fruit water extracts and 2) WhE: whole fruit ethanol extracts

따라서 피크닉 품종의 사과는 높은 항산화 활성을 가짐으로 인 해서 항노화를 위한 기능성 소재로 활용이 가능할 것으로 판단 되었다. 특히 DPPH radical 소거능의 경우 $25 \mu \mathrm{g} / \mathrm{mL}$ phenolic 정도의 매우 낮은 농도에서도 높은 항산화 활성을 나타내어, 소 량의 첨가만으로도 매우 우수한 항산화 효과를 기대할 수 있는 장점을 나타내었다.

\section{신육성 품종인 피크닉 사과 추출물의 항염중(hyaluronidase[HAase] 저해) 효과}

고분자 물질인 hyaluronic acid는 염증 형성과정에서 중요 인자 인 macrophage의 phagocytic ability를 저해하며, hyaluronic acid의 분해산물은 피부에 발생한 상처가 치유되는 과정에서 inflammation, fibrosis, collagen deposition을 증가시킨다. 또한 HAase는 일반적으로 생체 항상성 유지를 위해 불활성 형태로 리소좀 등에 존재하고 있지만, 신체적 상해나 류마티즘과 같은
염증성 질환이 발병하였을 때 활성화 되어 혈관계 투과성 및 염증반응에 관여하므로 염증 유발 물질로 알려져 있다[25].

염증 유발에 관련이 있는 효소인 HAase 저해 효과를 측정한 결과 Fig. 4에서와 같이 피크닉 사과의 water 추출물에서는 50$200 \mu \mathrm{g} / \mathrm{mL}$ 의 phenolic 농도에서 $4.40-4.62 \%$ 의 저해효과를 나타 내었으며, ethanol 추출물에서는 $50-200 \mu \mathrm{g} / \mathrm{mL}$ 의 phenolic 농도 에서 1.40-4.39\%의 저해효과를 나타내었다. Positive control로 사용한 tannic acid보다는 낮은 억제효과를 나타내었지만, 피크 닉 사과 추출물의 첨가 농도를 높인다면 어느 정도 효과가 발 현되리라고 판단되었다.

신육성품종 피크닉사과 추출물의 항당뇨( $\alpha$-amylase 저해, $\alpha$ gulcosidase 저해) 효과

탄수화물의 주종인 전분은 장관에서 $\alpha$-amylase에 의해 그리고 소장의 maltase에 의해 glucose로 가수분해되어 결국 혈류로 흡 수되어 혈당량 및 insulin level의 상승을 가져온다. 따라서 $\alpha$ amylase와 같은 효소의 작용을 제한 조절 할 수 있을 경우 전 분의 소화속도를 지연시킴으로써 그 흡수 kinetics 및 혈당량의 분포에 영향을 미치게 되어 탄수화물의 조절이상으로 기인한 당 뇨증상이나 비만증상의 환자에게 있어서 식이요법의 치료효과 를 증가 시킬 수 있다[26,27].

피크닉 사과 추출물의 $\alpha$-amylase 저해 효과를 측정한 결과 Fig. $5 \mathrm{~A}$ 에서와 같이 피크닉 사과의 water과 ethanol 추출물 50$200 \mu \mathrm{g} / \mathrm{mL}$ 의 phenolic 농도에서 각각 $2.53-2.61,2.29-2.31 \%$ 의 낮은 저해효과를 나타내었다.

a-Glucosidase는 소장 융모막에 존재하며 이당류나 다당류들 을 보다 작은 단당류로 분해하여 당의 흡수를 촉진시켜 혈당 상승작용을 일으킨다. 특히 식후 30 분이 경과 시 당의 흡수가 촉진되어 혈당이 증가하는데, 당뇨병 환자의 경우 급격히 상승 하는 과도한 혈당 및 고혈당증이 지속됨에 따라 발생하는 활성 산소들로 인해 당뇨병의 복합증세인 신경장애, 신장장해, 그리 고 망막증 등과 같은 질병이 발생하게 된다[28,29].

효모기원 $\alpha$-glucosidase 활성저해 효과를 측정한 결과 Fig. $5 \mathrm{~B}$ 에서와 같이 피크닉 사과의 water 추출물에서는 $50-200 \mu \mathrm{g} /$ $\mathrm{mL}$ 의 phenolic 농도에서 7.74-67.37\%의 저해 효과를 나타내었
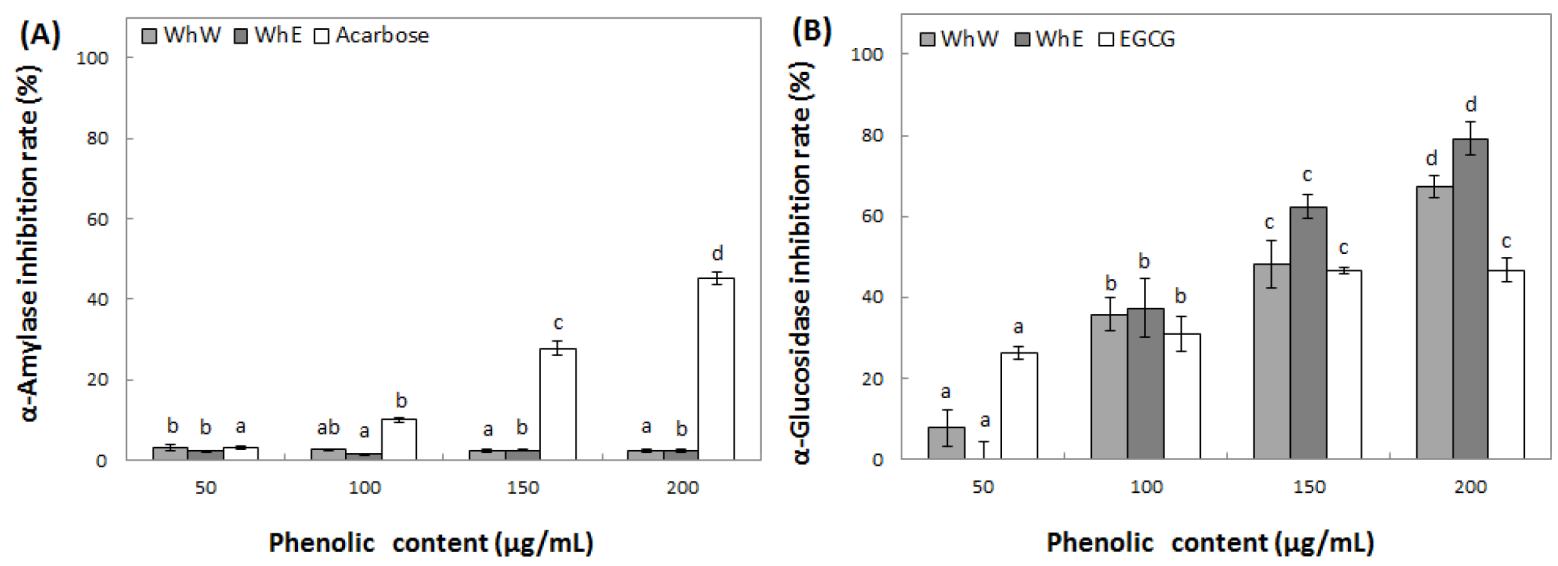

Fig. 5 Inhibition activity of water and ethanol extracts from Picnic apple on -amylase (A) and -glucosidase (B). Means with different superscript letters are significantly different at $p<0.05$ by a Duncan's multiple range tests. 1$)$ WhW: whole fruit water extracts and 2) WhE: whole fruit ethanol extracts 

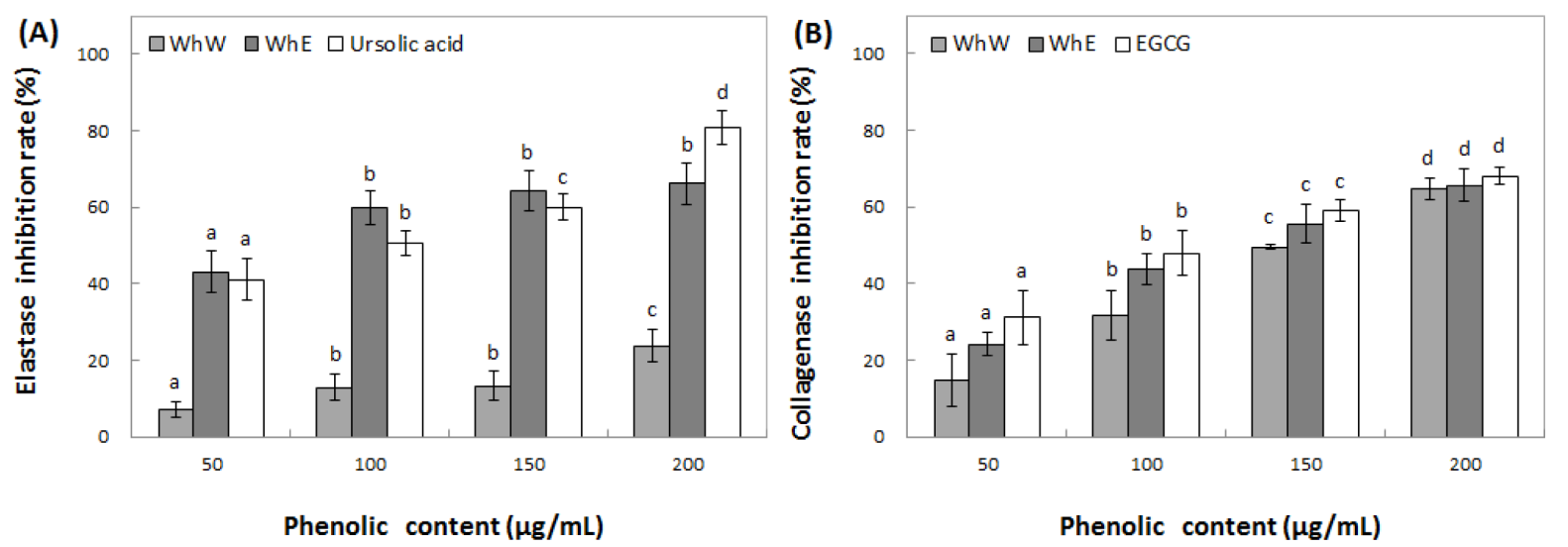

Fig. 6 Inhibition activity of water and ethanol extracts from Picnic apple on elastase (A) and collagenase (B). Means with different superscript letters are significantly different at $p<0.05$ by a Duncan's multiple range tests. 1) WhW: whole fruit water extracts and 2) WhE: whole fruit ethanol extracts

고, ethanol 추출물에서는 $50-200 \mu \mathrm{g} / \mathrm{mL}$ 의 phenolic 농도에서 $0.00-79.16 \%$ 의 저해 효과를 나타내었다. 따라서 피크닉 사과 추 출물이 탄수화물 분해 효소의 활성을 저해하는 것으로 확인되 었다. 위의 결과에 따라 피크닉 사과 추출물의 당분해 억제효 과를 확인하였고 기능성 식품분야에서 기능성 신소재로 적용 가 능하다고 판단되었다.

\section{신육성품종 피크닉사과 추출물의 주름개선 효과}

피부의 구조 단백질인 elastin은 피부가 damage를 입거나 노화 가 진행됨에 따라 생성량이 감소하게되고, 피부의 노화 정도에 따라 type-1 collagenase의 생합성이 증가하여 collagen 단백질 의 분해를 유도하여 피부탄력을 떨어뜨림으로서 피부 주름의 생 성을 발생시킨다[30]. 피부탄력성 섬유(elastin)을 분해하는 효소 인 elastase는 인체의 중성구 과립구 내에 존재하며 elastase의 저해효과는 피부 주름의 개선을 의미한다[31].

인체의 피부탄력을 유지해주는 elastin을 분해하여 피부 주름 을 생성시키는 효소인 elastase의 저해 효과를 측정한 결과 Fig. $6 \mathrm{~A}$ 에서와 같이 피크닉 사과의 water 추출물에서는 $50-200 \mu \mathrm{g} /$ $\mathrm{mL}$ 의 phenolic 농도에서 $7.14-23.70 \%$ 의 저해 효과를 나타내었 고, ethanol 추출물에서는 $50-200 \mu \mathrm{g} / \mathrm{mL}$ 의 phenolic 농도에서 43.13-66.29\%의 저해 효과를 나타내었다. Positive control로 사 용한 ursolic acid는 $50-200 \mu \mathrm{g} / \mathrm{mL}$ 의 농도에서 $20.16-43.47 \%$ 의 저해 효과보다 상대적으로 더 높은 저해효과를 나타내었다.

Collagen은 피부의 진피층을 지탱하는 기계적 견고성과 결합 조직의 저항력, 세포분할과 분화를 유도하는 기능을 가지고 있 으며, 자연노화 같은 내적요인과 외부 유해 환경에의 노출, 스 트레스 증가, 자외선 조사에 의한 광노화와 같은 외적 요인에 의해 collagenase의 활성이 증가하게 되고, 이러한 반응은 collagen의 감소를 유발하게 되며, 결국 피부의 탄력을 저하시 켜 주름과 피부쳐짐의 원인이 된다고 보고되어 있다[32].

Collagen을 분해하는 enzyme인 collagenase를 이용하여 저해 효과를 측정한 결과 Fig. $6 \mathrm{~B}$ 에서와 같이 피크닉 사과의 water 추출물에서는 $50-200 \mu \mathrm{g} / \mathrm{mL}$ 의 phenolic 농도에서 $14.77-64.83 \%$ 의 저해 효과를 나타내었고, 피크닉 사과의 ethanol 추출물에서 는 $50-200 \mu \mathrm{g} / \mathrm{mL}$ 의 phenolic 농도에서 24.13-65.70\%의 높은 저해 효과를 나타내었다. 따라서 피크닉 사과의 추출물은 피부
탄력을 유지하는데 중요한 단백질인 elastin과 collagen을 분해 하여 주름 유발에 영향을 미치는 enzyme인 elastase 및 collagenase를 억제하여 피부 주름개선 효과에 긍정적인 효과를 미치는 것으로 확인되었다.

상기의 결과에서와 같이 피크닉 품종의 사과는 기능성식품과 기능성 화장품 활성 검정에서 매우 우수한 생리활성을 가지며, 산업화를 위한 기능성 소재로 활용이 가능할 것으로 판단되었다.

\section{초 록}

신육성품종 피크닉 사과로부터 phenolic compounds를 추출 후 기능성 식품 및 기능성 화장품 활성을 검정하여 신육성 품종 피크닉사과의 기능성 소재 활용가능성을 살펴보았다. 피크닉 사 과로부터 생리활성으로 작용하는 phenolic 화합물을 추출하기 위하여 water과 ethanol로 추출하였을 때 각각 $6.81,13.25 \mathrm{mg} /$ $\mathrm{g}$ 의 비교적 높은 phenolic 함량을 나타내었다. 피크닉 사과 추 출물의 1,1-diphenyl-2-picrylhydrazyl (DPPH), 2,2'-azinobis-(3ethylbenzothiazoline-6-sulfonic acid (ABTS) radical 소거능은 water과 ethanol 추출물 $100 \mu \mathrm{g} / \mathrm{mL}$ phenolic 농도에서 각각 $87.69,90.55 \%$ 와 $98.44,96.95 \%$ 의 매우 높은 $\mathrm{DPPH}$ 및 $\mathrm{ABTS}$ 전자공여능을 나타내었다. PF는 water과 ethanol 추출물 $100 \mu \mathrm{g} /$ $\mathrm{mL}$ phenolics 농도에서 각각 $2.33,2.40 \mathrm{PF}$ 를 나타내었으며, thiobarbituric acid reactive substances는 $100 \mu \mathrm{g} / \mathrm{mL}$ phenolics 농도에서 water 추출물은 $56.05 \%$, ethanol 추출물은 $84.19 \%$ 의 항산화능을 나타내어, 피크닉 사과는 항산화 효과가 우수하여 노화방지를 위한 천연 항산화제로 활용가능성이 매우 높은 것 으로 판단하였다. 피크닉 사과 추출물의 hyaluronidase 저해 효 과를 측정한 결과 water과 ethanol 추출물에서 3-4\% 정도의 낮 은 저해 효과를 나타내었으며, 당분해 억제를 통해 항당뇨 효 과를 나타내는 $\alpha$-glucosidase 저해 효과를 측정한 결과 ethanol 추출물에서는 $200 \mu \mathrm{g} / \mathrm{mL}$ phenolics 농도에서 $50.34 \%$ 의 우수한 저해 효과를 나타내었다. 주름개선 효과를 측정하는 elastase 및 collagenase 저해 효과는 $200 \mu \mathrm{g} / \mathrm{mL}$ phenolics 농도에서 water 과 ethanol 추출물에서 각각 $31.77,48.71$ 와 $44.43,52.78 \%$ 의 저해 효과를 나타내었다. 위의 결과에 따라 피크닉 사과 추출 
물의 항산화, 항염증, 당분해 억제 및 주름개선 효과를 확인하 였고, 기능성 식품 및 기능성 화장품의 기능성 소재로 활용가 능성이 매우 높은 것으로 판단하였다.

Keywords 기능성식품 · 미용식품 · 생리활성 · 신육성품종 · 피 크닉사과

감사의 글 본 연구는 2017년도 농촌진흥청 어젠다사업(과제번호: PJ01245503, 사과 신육성 품종 이용성 증대 연구)의 연구비 지원에 의해 연구되었으며, 이 에 감사드립니다.

\section{References}

1. Korea Rural Economic Institute (2018) Agricultural Outlook 2018: Future of Agriculture and Rural Communities with the People, Korea

2. Wolfe KL, Liu RH (2003) Apple peels as a value-added food ingredient. J Agric Food Chem 51: 1676-1683

3. Li L, Tsao R, Yang R, Liu C, Zhu H, Young JC (2006) Polyphenolic profiles and antioxidant activities of heartnut (Juglans ailanthifolia var. cordiformis) and Persian walnut(Juglans regia L.). J agric food chem 54: 8033-8040

4. Feliciano RP, Antunes C, Ramos A, Serra AT, Figueira ME, Duarte CM, Bronze MR (2010) Characterization of traditional and exotic apple varieties from Portugal. Part 1-Nutritional, phytochemical and sensory evaluation. J funct foods 2 : $35-45$

5. Eberhardt MV, Lee CY, Liu RH (2000) Nutrition: Antioxidant activity of fresh apples. Nature 405: 903-908

6. Lee KW, Kim YJ, Kim DO, Lee HJ, Lee CY (2003) Major phenolics in apple and their contribution to the total antioxidant capacity. J Agric Food Chem 51: 6516-6520

7. Jedrychowski W, Maugeri U, Pac A, Sochacka-Tatara E, Galas A (2009) Reduced risk of colorectal cancer and regular consumption of apples: Hospital based case-control study in Poland. Central European J Med 4: 320-326

8. Sul D, Kim HS, Lee D, Joo SS, Hwang KW, Park SY (2009) Protective effect of caffeic acid against beta-amyloid-induced neurotoxicity by the inhibition of calcium influx and tau phosphorylation. Life sciences, 84: 257-262

9. Folin O, Denis W (1912) On phoshotungstic-phosphomolybdic compounds as color reagents. J Biol Chem, 12: 239-243

10. Blois MS (1958) Antioxidant determination by the use of stable free radical. Nature 181; 1199-1200

11. Pellegrini N, Re R, Yang M, Rice-Evans C (1998) Screening of dietary carotenoids and carotenoid-rich fruit extracts for antioxidant activities applying 2,2'-azinobis (3-ethylbenzothiazoline-6-sulfonic acid) radical cation decolorization assay. Methods Enzymol 299: 379-389

12. Andarwulan N, Shetty K (1999) Phenolic content in differentiated tissue cultures of untransformed and agrobacterium-transformed roots of anise (Pimpinella anisum L.). J Agric Food Chem 47: 1776-1780
13. Buege JA, Aust SD (1978) Microsomal lipid peroxidation. Method Enzymol 52: 302-310

14. Dorfman A, Ott ML (1948) A turbidimetric method for the assay of hyaluronidase. J Biol Chem 172: 367-375

15. Kraunsoe JA, Claridge TD, Lowe G (1996) Inhibition of human leukocyte and porcine pancreatic elastase by homologues of bovine pancreatic trypsin inhibitor. Biochem 35: 9090-9096

16. Wunsch E, Heidrich HG (1963) Zur quantitativen bestimmung der kollagenase. Hoppe-Seyler ${ }^{\circ}$ Øs Z Physiol Chem 333: 149-151

17. Rice-Evans CA, Miller NJ, Paganga G (1996) Structure-antioxidant activity relationships of flavonoids and phenolic acids. Free Radic Biol Med 20: 933-956

18. Lee EH, Kim YJ, Kwon SI, Kim JH, Kang IK, Kim BO, Cho YJ (2018) Functional properties of newly bred green ball apple (Malus pumila Mill). Kor J Food Preserv 25: 837-845

19. Yun HJ, Lim SY, Hur JM, Jeong JW, Yang SH, Kim DH (2007) Changes of functional compounds in, and texture characteristics of apples during post-irradiation storage at different temperatures. Kor J Food Preserv 14: 239-246

20. Hwang IW, Kim CS, Chung SK (2011) The physicochemical qualities and antioxidant activities of apple juices marketed in Korea. Kor J Food Preserv 18: 700-705

21. Cheon JH (2015) Effects of Backhousia citriodora extracts on antioxidant activity and bone formation. MS Thesis. Silla University, Busan, Korea. p. 4-6

22. Farag RS, Badei AZMA, Hewedi FM, El-Baroty GSA (1989) Antioxidant activity of some spice essential oils on linoleic acid oxidation in aqueous media. J Am Oil Chem Soc 66: 792-799

23. Frei B (1994) Natural antioxidants in human health and disease. Academic Press Publisher, Cambridge, MA, USA. p. 40-55

24. Borrello S, Seccia A, Galeotti T, Bartoli GM, Farallo E, Serri F (1984) Protective enzymes in human epidermal carcinomas and psoriasis. Arch Dermatol Res 276: 338-340

25. Ghosh P (1994) The role of hyaluronic acid (hyaluronan) in health and disease:Interactions with cells, cartilage and components of synovial fluid. Clin Exp Rheumatol 12: 75-82

26. Brodbeck U (1980) Enzyme inhibitors. Verlag Chemie Publisher, Weinheim, Germany. p. 19

27. Puls W, Keup U, Krause HP, Thomas G, Hoffmeister F (1997) Glucosidase inhibition. A new approach to the treatment of diabetes, obesity, and hyperlipoproteinaemia. Naturwissenschaften 64: 536-537

28. Hanefeld M (1998) The role of acarbose in the treatment of non-insulindependent diabetes mellitus. J Diabetes Complications 12: 228-237

29. McDougall GJ, Stewart D (2005) The inhibitory effects of berry polyphenols on digestive enzymes. Biofactors 23: 189-195

30. Lee SJ, Kwon YY, Cho SW, Kwon HS, Shin WC (2013) Effects of Ehwa Makgeolli containing oriental herbs on skin whitening and wrinkles. J Kor Soc Food Sci Nutr 42: 550-555

31. Lee JY, An BJ (2012) Whitening and anti-wrinkling effects of fractions from Prunus persica Flos. Kor J Micro Biotech 40: 364-370

32. Giacomoni PU, Rein G (2001) Factors of skin ageing sharecommon mechanisms. Biogerontology 2: 219-229 